\title{
THE DIALYZABILITY OF THE PRESSOR AND ANTIDIURETIC ACTIVITIES OF PITRESSIN
}

\author{
BY WAYNE DONALDSON
}

(From the Research Laboratories, Parke, Davis and Company, Detroit, Michigan)

(Received for publication April 4, 1947)

According to the present extent of our knowledge it appears that the pressor and the antidiuretic activities of Pitressin ${ }^{1}$ both reside in the same substance. Since Kamm (1) showed that the pressor activity dialyzes from aqueous solution, the antidiuretic activity should dialyze also. But Ralli (2) found that when Pitressin mixed with normal urine was dialyzed against water the full antidiuretic activity for rats remained in the non-dialyzable fraction. This suggested that urine might in some way inhibit the dialysis of Pitressin. On the other hand, if pressor activity dialyzes and antidiuretic does not, dialysis would provide a means of separating the 2 activities.

Others (3) have reported that antidiuretic activity does not dialyze. However, Smith (4) early showed that all 3 posterior pituitary activities dialyzed, and Walker (5) demonstrated the presence of antidiuretic activity in the dialysate.

The purpose of the present experiment is to report the pressor activity for dogs and the antidiuretic activity for humans of the non-dialyzable residue following dialysis of Pitressin mixed with water and mixed with normal urine. The results suggest that both the pressor and the antidiuretic activities do dialyze, whether mixed with water or with urine.

\section{PREPARATION OF SOLUTIONS}

Five tests were made on each of 4 human subjects using the following preparations:
A. No injection-control
B. Pitressin (not dialyzed)
C. Pitressin dialyzed from water
D. Pitressin dialyzed from urine I
E. Pitressin dialyzed from urine II

Solution $C$. Twenty-five $\mathrm{ml}$. of Pitressin containing 20 p.u. per $\mathrm{ml}$. (total 500 ; p.u. = pressor units) was dialyzed for 6 hours in 24/32 inch Visking tubing against running distilled water at room temperature and with agitation of the tubing. The dialysis residue was diluted

1 Pitressin is a registered trade mark of Parke, Davis and Company. to $100 \mathrm{ml}$. with water containing 0.5 per cent chloretone. The solution (representing 5 p.u. per ml.) was filtered through a Seitz filter using a 1-inch E.K. pad.

Solution $B$. With no dialysis, $25 \mathrm{ml}$. of Pitressin was diluted in the same way and subjected to the same Seitz filtration. This filtration of the control would make it possible to detect any adsorption of pressor or antidiuretic activity by the filter pad.

Solution D. Ten ml. (200 p.u.) of Pitressin was mixed with $26 \mathrm{ml}$. of diuretic urine from a normal human being. This urine contained $2.41 \mathrm{mgm}$. of solids per milliliter. The mixture was dialyzed as above; the dialysis residue was made to $40 \mathrm{ml}$. with water and Seitz filtered. The final solution represented 5 p.u. per ml.

Solution $E$. To eliminate the possibility that the urine effect described by Ralli was quantitatively dependent on some urinary constituent, it seemed desirable to increase the ratio of urinary solids to pressor units. Ten $\mathrm{ml}$. (200 p.u.) of Pitressin was mixed with $1,000 \mathrm{ml}$. of normal human urine having $\mathrm{pH} 5.82$, solids $36.6 \mathrm{mgm}$. per $\mathrm{ml}$. This solution was dialyzed overnight (17 hours) to specific resistance $14,100 \mathrm{ohms}$ and $\mathrm{pH} 6.05$. One-fourth of the dialysis residue was dried by appropriate means, and the resulting powder was taken up in $10 \mathrm{ml}$. of sterile water containing chloretone. The preparation was an amber liquid containing suspended material. Each milliliter represented 5 p.u. and $25 \mathrm{ml}$. of the normal urine.

\section{PROCEDURE}

The antidiuretic activity was tested in 4 normal human subjects who continued their usual work during the test period. Each solution was tested in all 4 subjects on the same day. No food or water was taken after 10 p.m. of the preceding night, the bladder was emptied at 8 a.m., the test solution was injected, and $1,000 \mathrm{ml}$. of water was taken by mouth at the same time. The dose in each case was $0.1 \mathrm{ml}$. representing 0.5 p.u., which was given into the muscle of the upper arm. Urine was voided at 30minute intervals and the cumulative excretion plotted against time as shown in Figure 1. Each solution was also assayed for pressor activity in dogs.

\section{RESULTS}

In every subject urine excretion was significantly delayed by 0.5 p.u. of undialyzed Pitressin, as shown in Figure 1. On the other hand, none of the dialyzed samples, whether from water or urine, resulted in a comparable delaying effect; the effect 

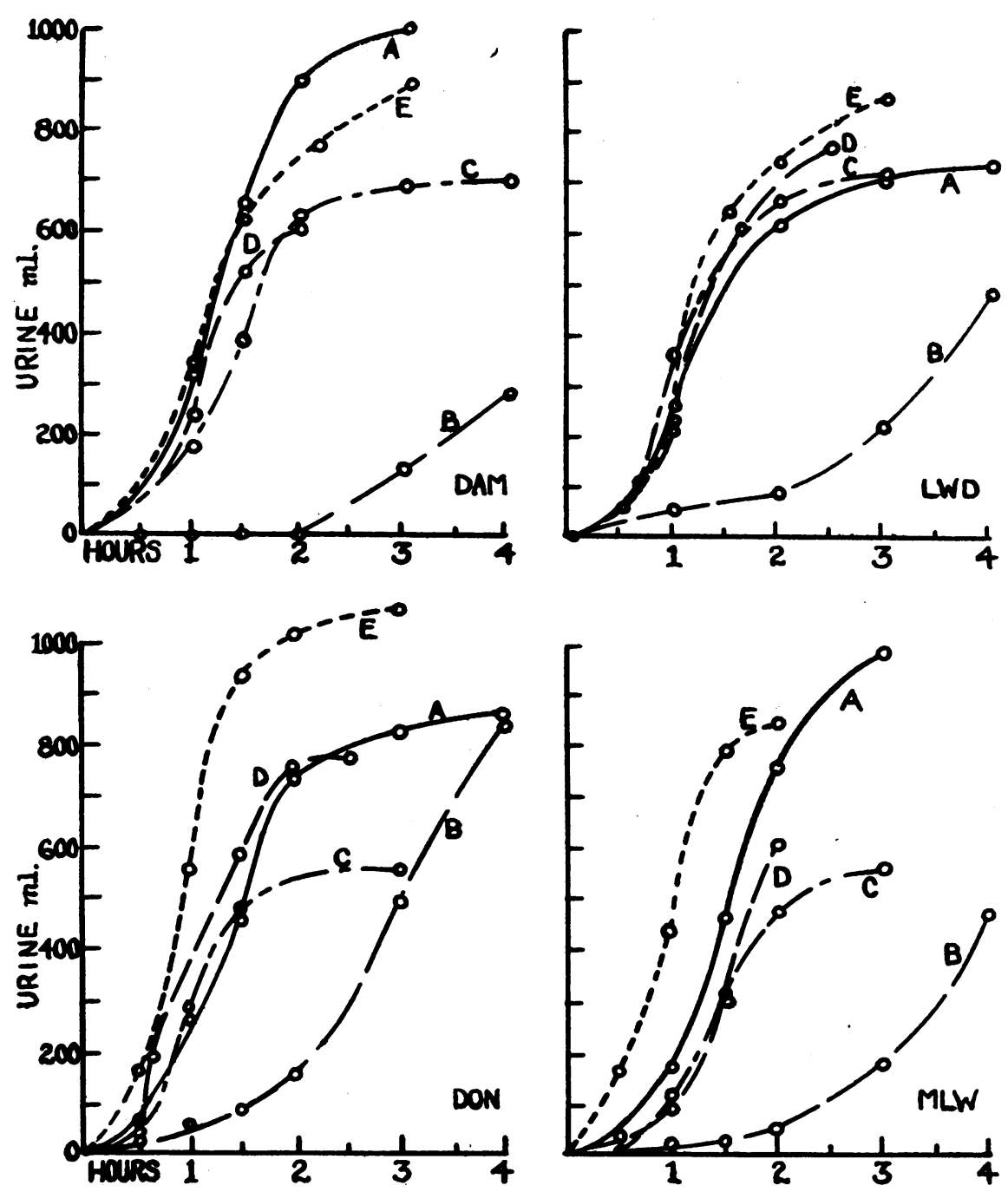

Fig. 1. Effect of Dialysis on Antidiuretic Activity of Pitressin Solutions

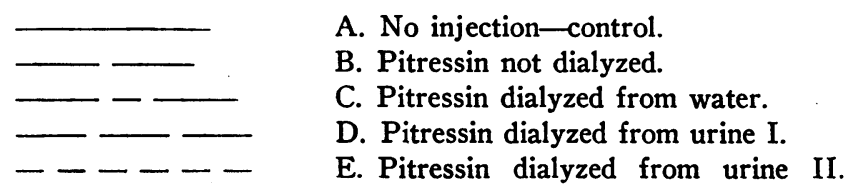

of such samples was more nearly like that of "no injection."

The pressor assay report was as follows:

B. Pitressin. Not dialyzed-

4.5 p.u. per $\mathrm{ml}$.

C. Pitressin dialyzed from water-

Much less than 0.1 p.u. per $\mathrm{ml}$.

D. Pitressin dialyzed from urine I-

Less than 0.1 p.u. per $\mathrm{ml}$.

E. Pitressin dialyzed from urine II-

Less than 0.1 p.u. per $\mathrm{ml}$.
Thus, the pressor activity remained in the undialyzed preparation, but was lost from all dialyzed solutions.

\section{CONCLUSIONS}

When mixtures of Pitressin with water or with urine were dialyzed, both the pressor and antidiuretic activities disappeared from the dialysis residue. 
The author wishes to express appreciation to Dr. D. A. McGinty for helpful suggestions, to Mr. L. W. Rowe for pressor assays, to Miss M. L. Wilson, Mr. D. C. Neubaum and Miss S. C. McKinsey for technical assistance.

\section{BIBLIOGRAPHY}

1. Kamm, O., The dialysis of pituitary extracts. Science, 1928, 67, 199.

2. Ralli, E. P., Robson, J. S., Clarke, D., and Hoagland, C. L., Factors influencing ascites in patients with cirrhosis of the liver. J. Clin. Invest., 1945, $24,316$.

3. Gilman, A., and Goodman, L., The secretory response of the posterior pituitary to the need for water conservation. J. Physiol., 1937, 90, 113.

Boylston, G. A., and Ivy, A. C., An antidiuretic substance present in the urine of dehydrated rats. Proc. Soc. Exper. Biol. \& Med., 1938, 38, 644.
Ingram, W. R., Ladd, L., and Benbow, J. T., The excretion of antidiuretic substance and its relation to the hypothalamico-hypophyseal system in cats. Am. J. Physiol., 1939, 127, 544.

Teel, H. M., and Reid, D. E., Observations upon the occurrence of an antidiuretic substance in the urine of patients with pre-eclampsia and eclampsia. Endocrinology, 1939, 24, 297.

Robinson, F. H., and Farr, L. E., The relation between clinical edema and the excretion of an antidiuretic substance in the urine. Ann. Int. Med., 1940, 14, 42.

4. Smith, M. I., and McClosky, W. T., On the dialysis of the physiologically active constituents of the infundibulum. J. Pharmacol. \& Exper. Therap., 1924, 24, 391.

5. Walker, A. M., Experiments upon the relation between the pituitary gland and water diuresis. Am. J. Physiol., 1939, 127, 519. 